\title{
30. Water footprints: Policy relevant or one-dimensional indicators?
}

\author{
Dennis Wichelns \\ National University of Singapore, Singapore
}

Water footprints are gaining traction in policy circles in several countries. In Spain, the Ministry of the Environment requires the discussion of water footprints in river basin plans that are prepared in compliance with the European Union Water Framework Directive (Aldaya et al. 2010). In the Netherlands, the Dutch House of Representatives has produced a motion requesting

that the government, in its economic policy, aim for Dutch companies to present their water footprint and to reduce this footprint in those areas that are affected by water scarcity, for example, by actively addressing companies that receive support through export guarantees or innovation subsidies to reduce their water footprints, and to request that these companies calculate their water footprints and include this information in their sustainability reports. (Witmer \& Cleij 2012)

In India, the Ministry of Water Resources convened a seminar on water footprints in New Delhi as part of India Water Week 2013. Several statements regarding water footprints appear in India's new National Water Policy (Government of India 2012). The statements, which appear in the section pertaining to demand management and water use efficiency, are as follows:

i. A system to evolve benchmarks for water uses for different purposes; i.e., water footprints and water auditing should be developed to promote and incentivise efficient use of water; and

ii. The project appraisal and environment impact assessment for water uses, particularly for industrial projects, should, inter-alia, include the analysis of water footprints.

Promoted originally as attractive indicators of the amount of water required to produce a good or service, it appears water footprints are now being considered and adopted as policy tools in national legislation. These examples from India, Spain and the Netherlands might be the first of many cases in which governments consider requiring firms to measure and reduce their water footprints.

Thus, it seems prudent to ask if water footprints are indeed policy relevant. Do water footprints provide the information and insight required to determine 
and design smart policy measures? Or might a focus on water footprints distract public officials from considering the broader set of inputs and impacts that require their attention when evaluating policy options? Might a focus on water footprints reduce net social benefits by motivating changes in water use that are not socially optimal?

It is likely that water footprints have succeeded in promoting greater awareness of the role of water in the production of many goods and services. In waterscarce areas, such an outcome is certainly desirable. Yet, even in water-scarce areas, water is just one of many inputs. In many settings, producers, consumers and public officials must consider issues that extend beyond water when crafting public policies, or when determining optimal production and consumption strategies. Information is needed regarding the opportunity costs of water in each setting and use. Insight is required also regarding the potential impacts of changes in water use on the livelihoods of individuals engaged in household or productive activities that require water as an input. The remainder of this chapter explores these issues in more detail.

\section{Information is not adequate}

Water footprints consider only the volume of water used in production, without considering other inputs or opportunity costs. Water volumes, alone, are not sufficient indicators of the benefits or costs of water use in any setting. The benefits and costs are functions of complex interactions involving physical, economic and social dimensions that are not contained or reflected in estimates of water footprints.

Comparing two water footprints across activities, locations, or time is not a helpful exercise if one does not have information regarding water scarcity conditions, the opportunity costs of water and water's role in supporting livelihoods in each setting. The water footprint of coffee might be 140 millilitres per cup, but that estimate provides no insight regarding the opportunity cost of water in the region where the coffee is produced, or the livelihoods earned by persons engaged in coffee production. Coffee produced in a country with abundant water might place no pressure on water supplies. Yet the activity might provide livelihoods to many residents who have few alternative sources of employment. Such aspects of water allocation decisions are not reflected in estimates of water footprints.

It is critical to consider both the opportunity cost of water (its scarcity value) and the opportunity cost of labor (alternative employment options) when evaluating policies that impact the allocation and use of water and other productive inputs. The water footprint of a coconut might be 2500 litres per kilogram, but most 
coconuts are produced in humid regions with abundant water supplies. In such settings, the opportunity cost of much of the water used in coconut production is not substantial, and local residents might have few alternatives to earning their livelihoods in the production and processing of coconuts.

\section{Inadequate consideration of costs and benefits}

Reducing water footprints is not always a desirable objective. Water footprints consider only water volumes, which are not sufficient indicators of the benefits or costs of water use in any setting. The benefits and costs are functions of complex interactions involving physical, economic and social dimensions that are not reflected in estimates of water footprints. For example, in many humid areas, the costs of reducing water deliveries to agriculture might exceed the benefits. The expenditures on labour, energy and equipment required to improve irrigation management might exceed the incremental value of reducing irrigation diversions, particularly in regions where surface runoff and deep percolation are useful resources.

Public officials must consider an array of questions pertaining to incremental benefits and costs, before reaching decisions regarding water-resource allocation and use. For example, they must consider the scarcity costs and environmental implications of non-water inputs in the production of goods and services. Examples include land, labour, energy, fertiliser, pesticides and machinery. Farm-level decisions regarding water use can also influence the amounts of these other inputs that are used. Efforts to reduce water footprints can result in greater use of electricity or farm machinery, thus increasing any off-farm impacts associated with those inputs.

One must also carefully consider inherent water scarcity conditions. It might be unwise to reduce water footprints in areas where water is not scarce, particularly if there are notable direct or indirect costs involved in such efforts. Water and other natural resources are critical inputs in household production functions for much of humanity. Efforts to reduce water footprints regionally or as part of a national strategy, can have severe implications on employment opportunities in agriculture and on household-level access to water resources. Public officials must consider the potential impacts of initiatives regarding water resources on food security and livelihoods, rather than simply attempting to reduce a volumetric measure of water use.

In addition to its role as a critical input in crop production, water is required for many activities at the household level (Smits et al. 2010; van Coppen and Smits 2010). In many areas of developing countries, individual and household water footprints are too small, rather than too large. Yet the manner in which water 
footprints generally are presented in the literature suggests that smaller is better, and that consumers and producers everywhere should endeavour to reduce their water footprints. A broader view that embraces the many benefits of water use would be more appropriate, particularly when discussing public policies.

\section{Summing up}

Water footprints do not provide the information or insight required to serve as a policy-relevant analytical construct. Analysts considering only water footprints cannot determine optimal policy measures or interventions. Water footprints do not describe the opportunity costs or the incremental benefits of water use in any setting, and they do not describe potential implications for livelihoods. Thus, policies designed on the basis of estimated water footprints might have the effect of moving society further away from desirable outcomes.

Dennis Wichelns is an agricultural and natural resource economist with many years of experience in production agriculture, academia and research institutes. $\mathrm{He}$ is presently Professor and Director of the Institute of Water Policy at the National University of Singapore. He has served as a Professor at the University of Rhode Island, California State University in Fresno, Hanover College and Indiana University Northwest. He has served also as a Senior Fellow with the International Water Management Institute (IWMI). From his base at the IWMI Headquarters in Colombo, Sri Lanka, Wichelns has worked with many international colleagues on a variety of studies regarding water, agriculture and livelihoods in several countries across Asia and Africa. He has also served as one of several Editors-in-Chief of Agricultural Water Management and as the founding Editor-in-Chief of Water Resources \& Rural Development.

\section{References}

Aldaya, M.M., Martínez-Santos, P. and Llamas, M.R., 2010. 'Incorporating the water footprint and virtual water into policy: reflections from the Mancha Occidental Region, Spain', Water Resources Management 24(5):941-58.

Government of India, 2012. 'National water policy', 5 August. Available at: http://mowr.gov.in/indexl .asp?linkid=201\&langid $=1$.

Smits, S., van Koppen, B., Moriarty, P. and Butterworth, J., 2010. 'Multiple-use services as an alternative to rural water supply services: a characterization of the approach', Water Alternatives 3(1):102-21. 
van Koppen, B. and Smits, S., 2010. 'Multiple-use water services: climbing the water ladder', Waterlines 29(1):5-20.

Witmer, M.C.H. and Cleij, P., 2012. 'Water footprint: useful for sustainability policies?', PBL Netherlands Environmental Agency, PBL Publication number: 500007001 . 
This text taken from Global Water: Issues and Insights by R. Quentin Grafton, Paul Wyrwoll, Chris White and David Allendes, published May 2014 by ANU Press, The Australian National University, Canberra, Australia. 